Acta Theriologica $36(1-2): 95$ - 107, 1991.

PL ISSN $0001-7051$

\title{
Comparison of craniological parameters in Mus musculus musculus Linnaeus, 1758 and Mus hortulanus Nordmann, 1840
}

\author{
Svetlana LYALYUKHINA, Elena KOTENKOVA, Wiera WALKOWA \\ and Krystyna ADAMCZYK
}

\begin{abstract}
Lyalyukhina S., Kotenkova E., Walkowa W. and Adamczyk K. 1991. Comparison of craniological parameters in Mus musculus musculus Linnaeus, 1758 and Mus hortulanus Nordmann, 1840. Acta theriol. 36: $95-107$.

To analyse craniological parameters of $M$. m. musculus and $M$. hortulanus, 14 measurements were taken, two indices were calculated, and three qualitative traits were considered. The material comprised 169 skulls of $M$. m. musculus captured in the European part of the U.S.S.R., in central Ukraine, and in Poland, and 225 skulls of M. hortulanus captured in central and south-eastern Ukraine and in Moldova. It has been found that these two species can be differentiated using the following parameters: breadth of zygomatic process of maxilla, index $\mathrm{K}$, zygomatic index, shape of masseter plate, and frequency of zygomatic foramen. In order to identify an individual to species, it is necessary to consider the total set of these characteristics, and first of all quantitative traits.

Kirovograd Teachers' Training Institute, Shevchenki 1, 316050 Kirovograd, USSR (SL); Institute of Evolutionary Morphology and Ecology of Animals, Academy of Sciences, Leninskij Prospect 33, 117071 Moscow, USSR (EK); Institute of Ecology, Polish Academy of Sciences, Department of Vertebrate Ecology, Dziekanów Leśny, 05-092 Łomianki, Poland (WW, KA)

Key words: craniological variation, differentiation, M. m. musculus, M. hortulanus
\end{abstract}

\section{Introduction}

Most researches argued that the house mouse, Mus musculus Linnaeus, 1758 has many forms, and they considered M. hortulanus Nordmann, 1840 as one of the subspecies of $M$. musculus (Argiropulo 1940, Schwarz and Schwarz 1943, Bobrinskij et al. 1965, Gromov and Baranova 1981, and others). According to other authors, M. m. musculus and M. hortulanus are separate species (Val'ch 1927, Pisareva 1948, Ladygina 1964, Thaler et al. 1981a, b; Marshall 1986 and other). Based on the study of the polymorphisms of proteins, Thaler et al. (1981a, b) have concluded that $M$.m.musculus and $M$. hortulanus are two sympatric species, genetically isolated under natural conditions. These species also differ in ecological parameters (Naumov 1940, Lyalyukhina 1984), eco-physiological characteristics (Lyalyukhina 1964) and ethological characteristics (Sokolov et al. 1983, 1990; Meshkova et al. 1984, 1986). They also show specific differences in olfactory signals (Sokolov et al. 1984, Kotenkova et al. 1989).

Poland and a large part of the USSR are occupied by M. m. musculus (Bonhomme et al. 1984, Thaler 1986). Transcaucasia is inhabited by hybrids of $M . m$. domesticus and $M . m$. bactrianus (Mezherin and Kotenkova 1989). M. m. musculus and M. hortulanus are sympatric 


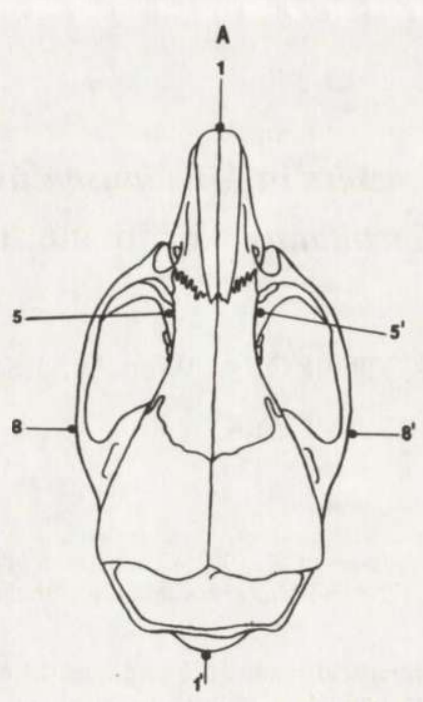

$\stackrel{1}{1,3}, 5 m$

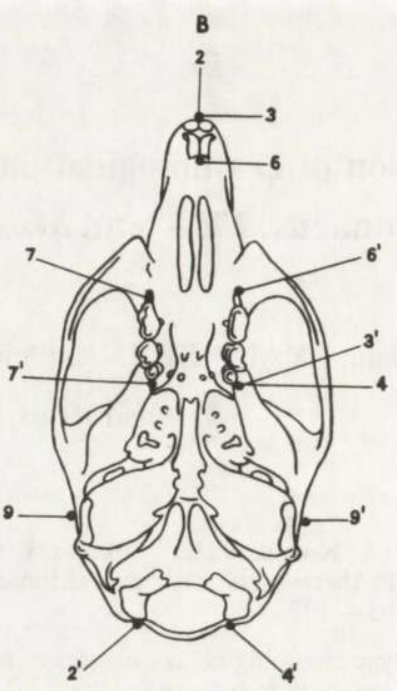

$\stackrel{1}{3}, \frac{3}{1}, 5 \mathrm{~m}$

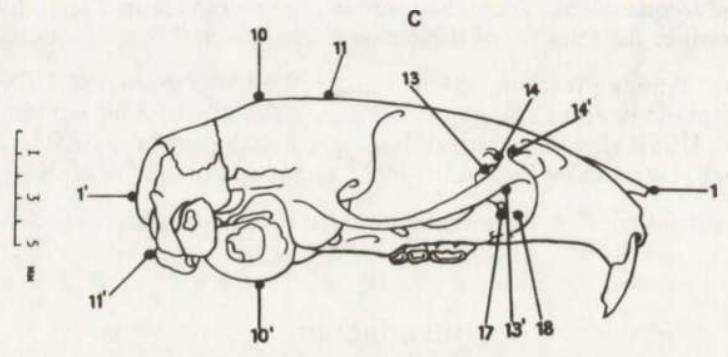

D
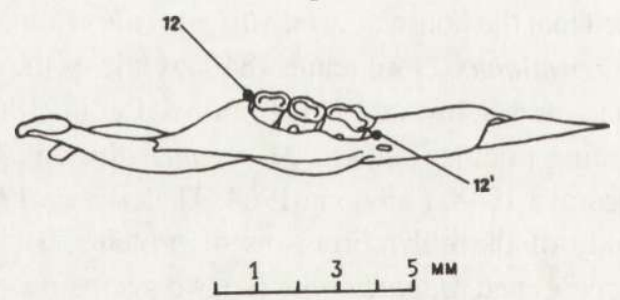

Fig 1. Skull characters used for the study (drafted by V. A. Lapshov). 1-1' - Profile length, 2-2' Condylobasal length, $3-3^{\prime}$ - Rostrum length, distance between the most distal point of pallatine process of premaxilla to the posterior edge of molar row, $4-4^{\prime}-$ Brain-case length, distance from the posterior edge of the last molar to the posterior edge of occipital condyle, 5-5' - Interorbital constriction, $6-6^{\prime}-$ Length $^{\prime}$ of diastema, $7-7^{\prime}$ - Length of maxillary tooth-row, $8-8^{\prime}-Z^{\prime}$ ygomatic breadth, $9-9^{\prime}-$ Maximum brain-case breadth, $10-10^{\prime}-$ Hight of brain-case through tympanic bullas, $11-11^{\prime}-$ Distance between occipital condyle and crossing of frontal and coronal sutures, $12-12^{\prime}-$ Length of mandibular tooth-row, $13-13^{\prime}-$ Breadth of zygomatic process of maxilla, $14-14^{\prime}-$ Minimum breadth of upper ramus of zygomatic process of maxilla,

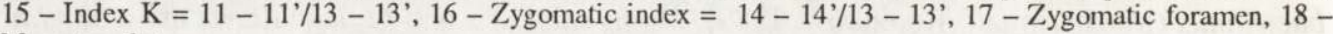
Masseter plate. 
in Ukraine and Moldova (Lyalyukhina 1984), and they do not cross under natural conditions (Mezherin 1987, Mezherin and Zagorodnjuk 1989).

The purpose of this paper is to describe the geographical variation, to check the validity of the formerly used and of other potential parameters distinguishing M. m. musculus and $M$. hortulanus, in particular when variations due to age are taken into account.

\section{Material and methods}

M. m. musculus used for craniological measurements were caught in dwelling places located in centralEuropean parts of the USSR (Moscow), central Ukraine (Kirovograd), and Poland (near Warsaw). M. hortulanus specimens were captured in agrocoenoses of central Ukraine (Zaporozhe region) and of Moldova (near Kishinev). The total material consisted of 169 skulls of $M$. m. musculus and 225 skulls of $M$. hortulanus of different ages

Table 1. Material used for the estimation of craniological parameters in M. m. musculus and M. hortulanus.

\begin{tabular}{llccc}
\hline \multirow{2}{*}{ Species } & Region & \multicolumn{3}{c}{ Number of individuals } \\
\cline { 3 - 4 } & & adult & subadult & juvenile \\
\hline \multirow{2}{*}{ M. m. musculus } & European USSR (Moscow) & 32 & - & - \\
& Central Ukraine (Kirovograd) & 39 & 22 & 19 \\
& Poland (near Warsaw) & 57 & - & - \\
\multirow{3}{*}{ M. hortulanus } & Central Ukraine (Kirovograd region) & 132 & 24 & 25 \\
& South-eastern Ukraine (Zaporozhe region) & 20 & - & - \\
& Moldova (Kishiniev region) & 24 & - & - \\
\hline
\end{tabular}

(Table 1). The age of animals was estimated from the tooth wear (Varshavskij 1950, Keller 1974) rather than from the lens weight, the latter being less reliable (Berry and Treslove 1968). Three age groups were distinguished: adults, subadults, and juveniles.

Skulls were measured by means of a slide calliper and MBS-1 microscope with a micrometer in the ocular. A total of 14 skull measurements were taken. These measurements are detailed in Fig. 1. In addition to the variables indicated in the figure we calculated index $\mathrm{K}$ as the ratio of distance between occipital condyle and crossing of frontal and coronal sutures (11)* to the breadth of zygomatic process of maxilla (13), and after Orsini et al. (1983), a zygomatic index was calculated as the ratio of the minimum breadth of upper ramus of zygomatic process of maxilla (14) to the breadth of zygomatic process of maxilla (13).

Besides, qualitative characteristics of skulls were recorded, i.e. (1) shape of the lower edge of enlarged part of zygomatic process of maxilla (masseter plate), (2) presence or absence of zygomatic foramen on masseter plate, (3) shape of coronal suture. These traits were proposed by Orsini et al. (1983) based on the analysis of skulls of the different forms of the house mouse, and used by Kratochvil (1986a, b) for diagnosis of different forms of mice of the genus Mus. The frequency of the occurrence of each of the qualitative parameters for M. m. musculus and M. hortulanus was calculated.

The significance level of at least 0.05 was used for all differences. 


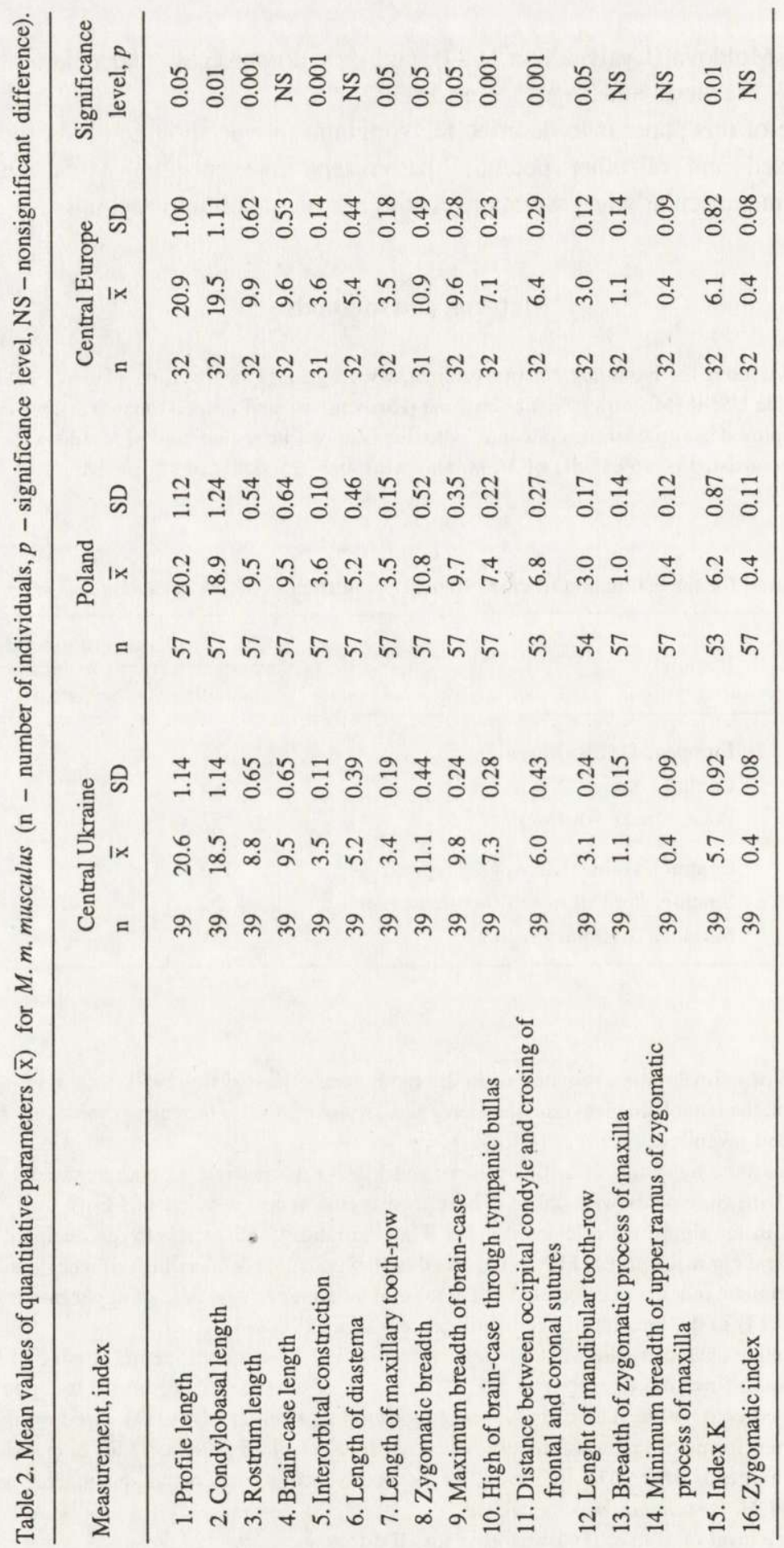




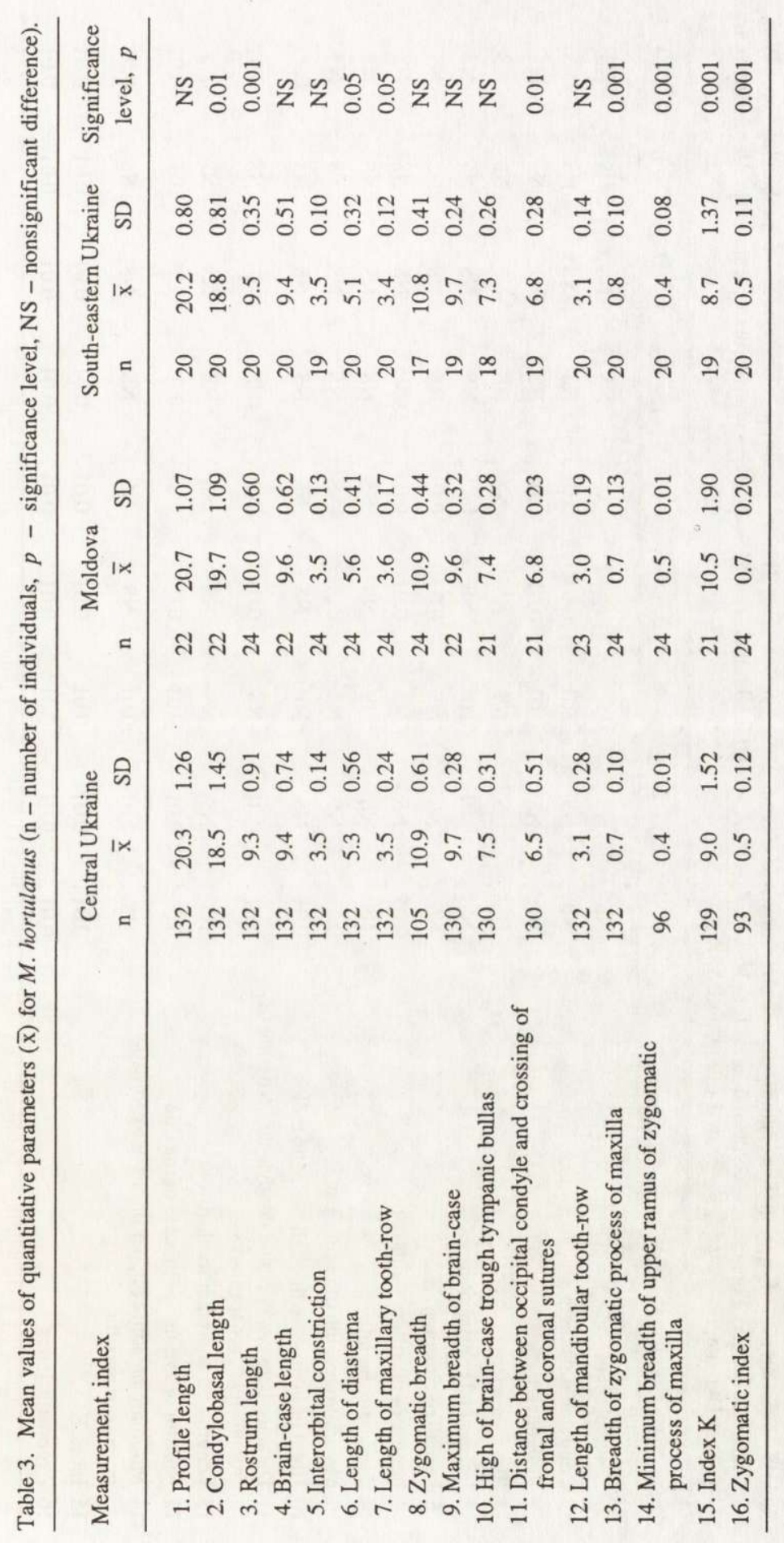




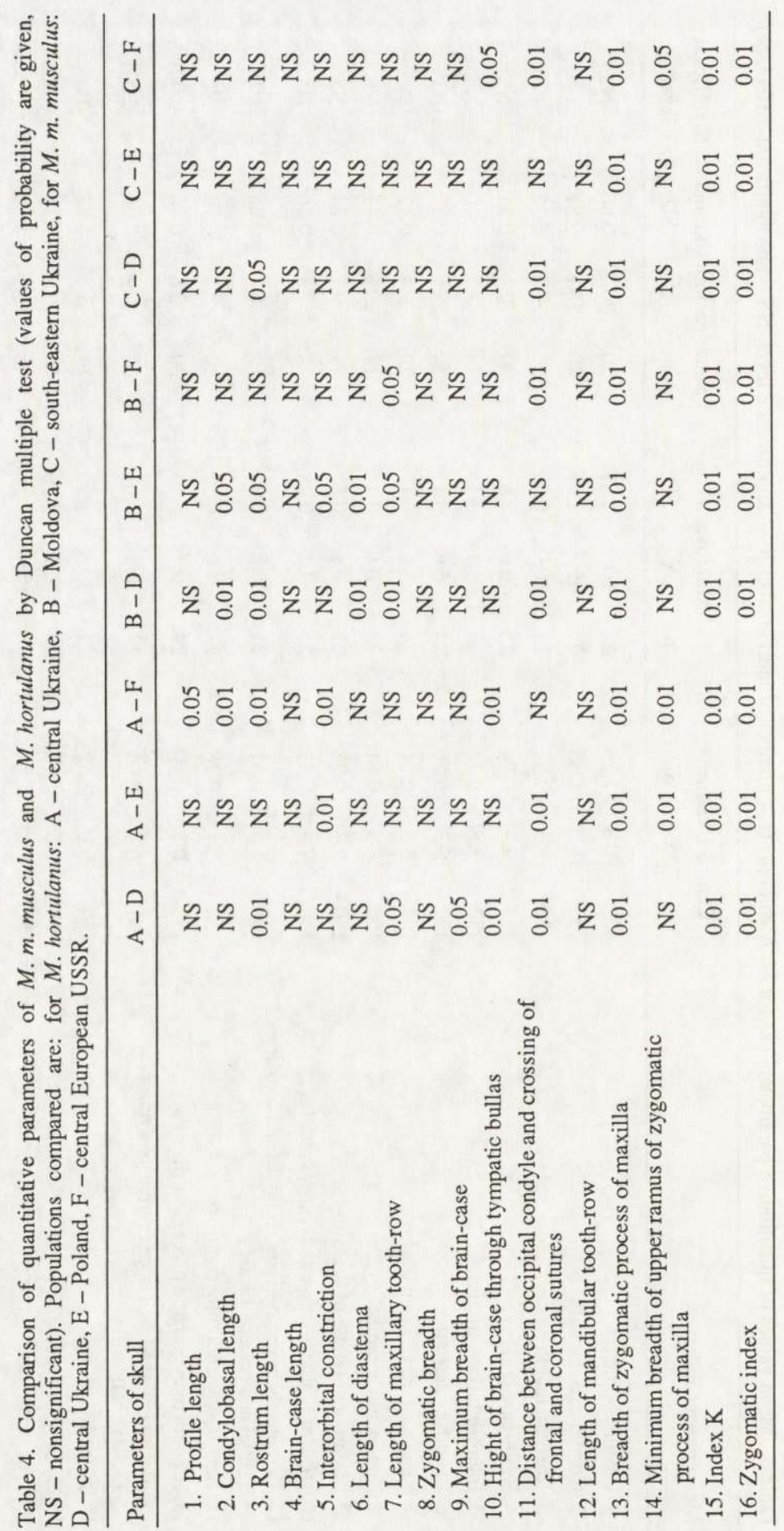




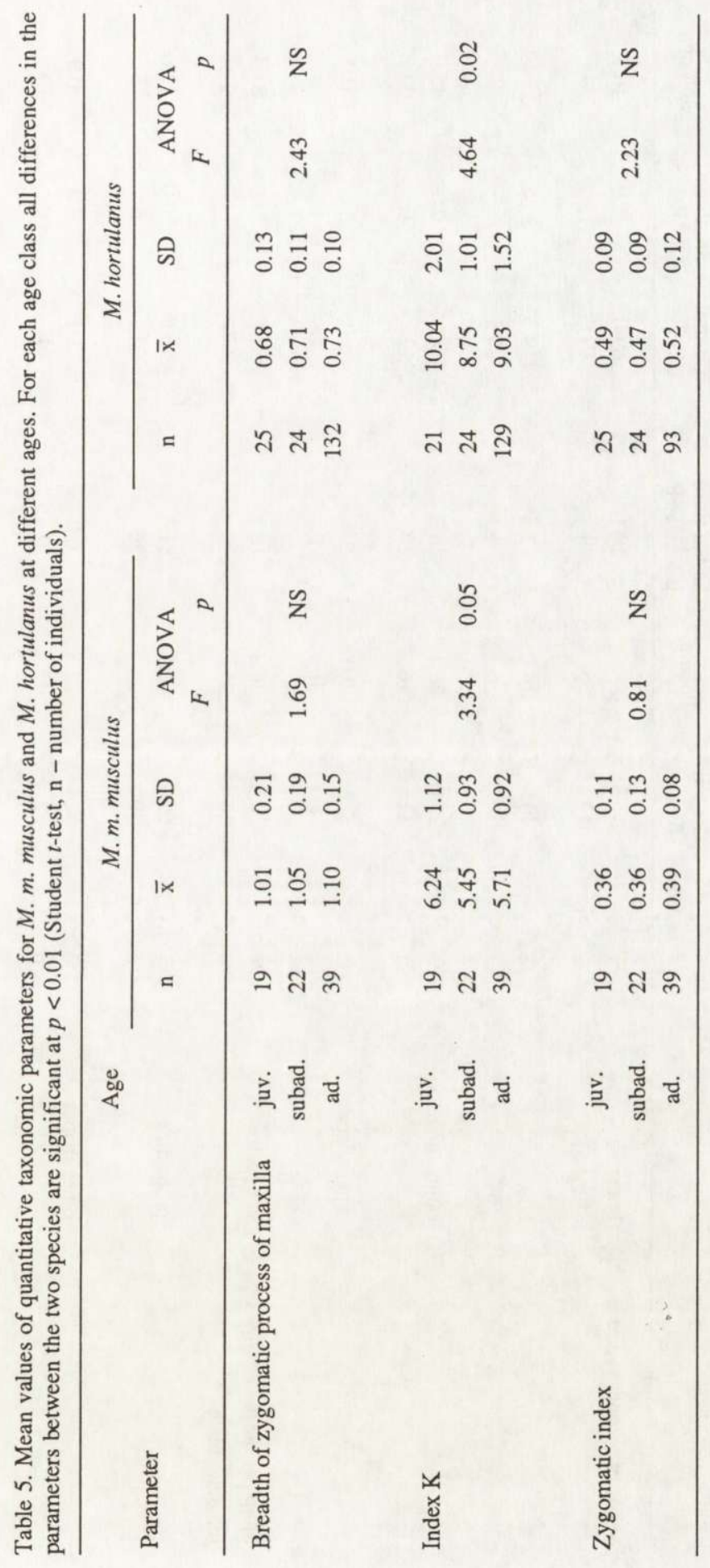




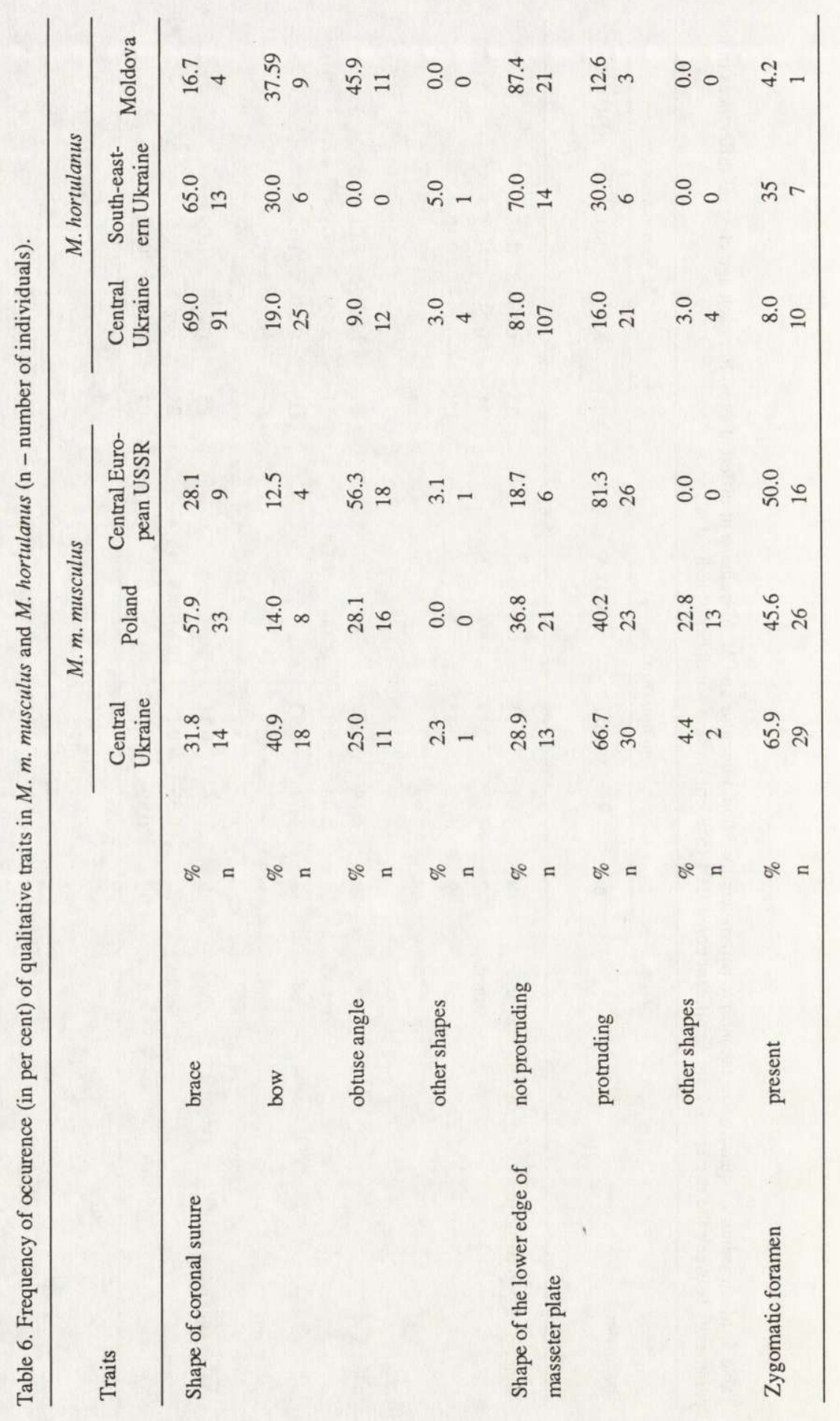




\section{Results}

Quantitative craniological parameters of $M$. m. musculus and $M$. hortulanus in different parts of their ranges

Analysis of variance was used to compare craniological measurements and indices of each species in different parts of the range. This analysis has shown that $M$. m. musculus living in different parts of the range show similarity in five parameters $(4,6,13,14$ and 16) and significant differences in 11 parameters $(1,2,3,5,7,8,9,10,11,12,15)$ (Table 2). $M$. hortulanus from various parts of Ukraine and Moldova were similar in seven parameters $(1,4,5,8,9,10,12)$ (Table 3$)$ and differed in nine parameters $(2,3,6,7,11,13,14,15,16)$.

The Duncan multiple test was used to compare quantitative parameters of skull between the two species. Using this test, it is possible to show similarities and differences in individual parameters between the two species from different regions. Thus, each parameter of M. m. musculus from the central European USSR was compared with respective parameters of $M$. hortulanus from central and south-eastern Ukraine and from Moldova. A similar comparison was made for M. m. musculus from central Ukraine and Poland. It has been found that $M$. hortulanus from each of the study areas significantly differs from $M . m$. musculus ir central European USSR, central Ukraine, and Poland with respect to three parameters: breadth of zygomatic process of maxilla, index $\mathrm{K}$, and zygomatic index $(13,15,16)$ (Table 4). For this reason these parameters are proposed as taxonomic characters.

Comparison of quantitative craniological parameters of $M$. m. musculus and $M$. hortulanus at different ages

Analysis of variance (ANOVA) was used to compare taxonomic parameters in three age classes (juvenile, subadult, adult) for M. m. musculus and $M$. hortulanus separately, and Student $t$-test for testing differences between these species. Within species the taxonomic parameters were similar, except for the index $\mathrm{K}$ (Table 5). Differences between $M . m$. musculus and $M$. hortulanus were statistically significant for each age class $(p<0.001)$ if the compared individuals were from the same or different age class. So individuals at different ages can be identified to species.

Qualitative craniological parameters of $M . m$. musculus and $M$. hortulanus in different parts of their ranges

In $M$. m. musculus various shapes of coronal suture occur with different frequency within the range of the species (Table 6). In central-European USSR, the posterior edge of frontal bones forms an obtuse angle for more than half of individuals. In mice from Poland, this shape is less frequent by half, and the most frequent shape of suture resembles a brace. The coronal suture of mice from central Ukraine is most frequently bow-like. A different picture emerged from the analysis of the shape of masseter plate. Typically, in $M . m$. musculus it tended to be round with a protruding lower egde. Only in Poland the proportions of individuals with protruding and not protruding edge of masseter plate were similar. The proportion of skulls with zygomatic foramen present was high and different in various parts of the range.

The coronal suture of $M$. hortulanus was typically of the shape of a brace, except for the individuals from Moldova where most frequently it formed an obtuse angle (Table 6). Most 
individuals of this species had masseter plate with not protruding lower edge. Zygomatic foramen was rare in individuals from Moldova and central Ukraine, but relatively frequent in those from south-eastern Ukraine.

The comparison of qualitative traits of $M . m$. musculus and $M$. hortulanus has shown that none of the proposed qualitative traits taken separately can be used for identification the species. However, because of differences in the frequency of the shape of the lower edge of masseter plate and zygomatic foramen, they can be helpful in mouse identification (Table 7).

Table 7. Craniological parameters differentiating between $M . m$. musculus and M. hortulanus.

\begin{tabular}{|c|c|c|}
\hline Parameter & M. m. musculus & M. hortulanus \\
\hline Breadth of zygomatic process of maxilla & $>1.0$ & $<0.8$ \\
\hline Index $\mathrm{K}$ & $4.5-6.6$ & $7.3-14.1$ \\
\hline Zygomatic index & $<0.42$ & $>0.50$ \\
\hline Shape of lower edge of masseter plate & $\begin{array}{l}\text { more often with protruding lo- } \\
\text { wer edge }\end{array}$ & $\begin{array}{l}\text { more often with nonprotruding } \\
\text { lower edge }\end{array}$ \\
\hline Zygomatic foramen & often present & often absent \\
\hline
\end{tabular}

\section{Discussion}

Long ago, zoologists noticed that house mice from various parts of their range differ in craniological traits. Agriropulo (1940), who considered the house mouse as a species comprising five subspecies, described the configuration, proportions, and structure of the skull of $M . m$. musculus, including the range of variation for nine parameters of the skull. His characteristics of skulls were however, limited to only superficial comparisons (e. g. relatively bigger, massive, or relatively smaller) and to some measurements. Numerical values of most of these measurements overlapped for different subspecies. As a result, the diagnostic value of such comparison was small. Ognev (1916) took measurements of $M$. hortulanus skulls. He suspected that this species differed at the level of subspecies from the synanthropic house mouse with respect to the length and proportions of some parts of the skull and in the shape of coronal suture. Gulij (1930) analysed geographical and age-related variations in craniometry of mice, he considered as $M$. hortulanus, presented an opposite view on the taxonomic value of these indices. He has concluded that most of the craniological traits cannot be used for the diagnosis of $M$. hortulanus. It should be noted, however, that the materials of Ognev (1916) and Gulij (1930) were likely to contain individuals of both $M$. hortulanus and M. m. musculus. Migulin (1937) was the first to note differences in the breadth of zygomatic process of maxilla (or, using his terminology, "zygoma hight in the anterior one third of its length") and proposed this trait for identification of mouse species. A similar view was presented by Sharleman (1937). According to Pisareva (1948), the value of this trait in M. m. musculus is twice that in $M$. hortulanus. In recent years, the taxonomy of the house mouse was revised by biochemists, and this gave rise to the reanimation of craniological parameters as less labour consuming and 
generally more accessible than biochemical methods (Marshall and Sage 1981, Kratochvíl 1986a, b, 1987).

Orsini et al. (1983) proposed a zygomatic index for diagnostic of M. musculus and $M$. hortzlanus. For six populations from Greece, Bulgaria, and Austria, they found the values of this index ranging from 0.45 to 0.48 for M. musculus and from 0.74 to 0.80 for M. spicilegus $(=M$. hertulanus). For $M$. musculus these values are comparable to our data (Table 2) but not for $M$. hrtulanus (Table 3). Presumably the value of this index varies in different parts of the range of $M$. hortulanus, or depends on measuring technique. This does not change, however, the fact that the values of the zygomatic index show significant differences between $M$. musculus and $M$. hortulanus in all the study areas, thus is a good diagnostic trait. Auffrey et al. (1990) have found that using this index it is possible to differentiate between Mus "spretoiles" and M. m. domesticus occurring in Israel.

In this paper we use the new index $\mathrm{K}$ to differentiate between $M$. m. musculus and $M$. hortulanus which yielded a parameter clearly different between these species. Differences in the values of this index between the species compared are greater than differences in the zygomatic index, facilitating their identification. We also calculated index $\mathrm{K}$ for $M$. hortulanus collected from eastern Ukraine (Dnepropetrovsk region) by Pisareva (1948). Its value $(K=9.8 \pm 0.6)$ totally agrees with our result (Table 3$)$. Thus, using zygomatic index and index $\mathrm{K}$, it is possible to indentify the species of individual mouse independently on the age of the animal.

Unlike Kratochvíl (1986a, b) and Orsini et al. (1983), we have found that none of the analysed qualitative traits separately can be used for differentiating between $M$. m. musculus and $M$. hortulanus. According to Orsini et al. (1983), each species has a distinct set of traits. For example, the lower edge of masseter plate in $M . m$. musculus is rounded and protruding forwards, and the zygomatic foramen is always present. Kratochvíl (1986a, b), shows a drawing of coronal suture which is similar to a triangle in this species. According to these authors, distinct qualitative traits are characteristic of $M$. hortulanus. Our data do not confirm those reported by Orsini $e t$ al. (1983), who show that the shape of masseter plate and the presence or absence of zygomatic foramen are important taxonomic traits. Our results show that each qualitative trait taken separately can specify individuals only with some probability. A high degree of the polymorphism of coronal suture reduces the diagnostic value of this trait. Gulij (1930) concluded that this trait was of a diagnostic value only when used with other traits, and we totally agree with him.

More complicated is the identification to species of individuals showing traits of both M. m. musculus and $M$. hortulanus. We analysed such individuals, and have found that most of them share only one trait of the other species. Only one individual of $M$. hortulanus from central Ukraine shared two traits with $M . m$. musculus, and another individual shared three traits (shape of coronal suture and the shape of the edge of masseter plate, and also the presence of zygomatic foramen). But the values of index $\mathrm{K}$ and of zygomatic index indicated that these individuals belonged to $M$. hortulanus. Similar results were obtained for one individual of M. m. musculus, in which the shape of the edge of masseter plate was typical of $M$. hortulanus, zygomatic foramen was absent, but the values of index $\mathrm{K}$ and zygomatic index showed that this was $M$. m. musculus. Thus, our study provides evidence that craniological parameters can 
reliably be used for diagnosis of $M . m$. musculus and $M$. hortulanus but only when a set of quantitative and qualitative traits is examined, i.e. breadth of zygomatic process of maxilla, index $\mathrm{K}$, zygomatic index, shape of lower edge of masseter plate, and the frequency of occurence of zygomatic foramen, and first of all, quantitative traits should be used (Table 7).

Acknowledgements: We wish to thank A. G. Mikhailenko from the Moldovan Plague Control Station for his assistance in material collecting, and dr I. Pavlinov and dr O. L. Rossolimo from Zoological Museum in Moscow for providing facilities for work on the collected material and to dr E. Le Boulenge from Catholic University in Louvain for comments on the text.

\section{References}

Argiropulo A. I. 1940. Semejstvo Muridae - myši. Mlekopitajuščie. Fauna SSSR. Izd. AN SSSR Moskva Leningrad, 2: 89-93.

Auffray J. C., Tchernov E., Bonhomme F., Meth G., Simson S. and Nevo E. 1990. Presence and ecological distribution of Mus "spretoides" and Mus musculus in Israel. Circum-Mediterranean vicariance in the genus Mus. Z. Säugetierk. 55: $1-10$.

Bobrinskij N. A., Kuznetsov B. A. and Kuzyakin A. P. 1965. Opredelitel' mlekopitajuščich SSSR. "Prosveščenie" Moskva: $1-382$.

Berry R. Y. and Truslove G. M. 1968. Age and eyes lens weight in the house mouse. J. Zool. 155: 247 - 252.

Bonhomme F., Catalan I., Britton-Davidian J., Verne M., Chapman K., Morivaki K., Nevo E. and Thaler L. 1984. Biochemical diversity and evolution in the genus Mus. Biochem. Genet. 22: $275-303$.

Gromov I. M. and Baranova G. I. 1981. Katalog mlekopitajuščich SSSR. Pliocen - sovremennost'. Nauka Leningrad: 1 - 456.

Gulij G. I. 1930: Sistematičeskije priznaki kurgančikovoj myši. Izvestia Severo-Kavkazskoj kraevoj stancii zaščity rastenij 5: $105-127$.

Keller A. 1974. Détermination de l'âge de Mus musculus Linné par l'usure de la dentition. Rev. Suisse Zool. 81: 839-844.

Kotenkova E. V., Osadchuck A. V. and Lyalyukhina S. J. 1989. Precopulatory isolating mechanisms between the house and mound-building mouse. Acta theriol. 34: $311-320$.

Kratochvíl i. 1986a. Intraspezifische Microevolution der Art Mus domesticus Rutty, 1772. Acta Sc. Nat. Bmo 20: 1-49.

Kratochvíl I. 1986b. Mus abbotti-eine klein-asiatisch-balkanische Art (Muridae-Mammalia). Folia Zool. 35: $3-20$.

Kratochvíl I. 1987. Der taxonomische Status der Form Mus hanuma. Folia Zool. 36: 97 - 102.

Ladygina N. M. 1964. K sravnitelnoj charakteristike kurgančikovoj i domovoj myšej. [In: Voprosy genetiki i ekologii] Charkov: $67-75$.

Lyalyukhina S. I. 1984. Sravnitel'noe issledovanie biologii domovoj (Mus musculus L.) i kurgančikovoj (M. hortulanus Nordm.) myšej v areale sovmestnogo obitanija. Avtoref. diss. kand. biol. nauk Moskva: 1-24.

Marshall I. T. and Sage R. D. 1981. Taxonomy of house mouse. [In: Biology of the house mouse. B. Y. Betty, ed.]. Symp. zool. Soc. Lond. 47: $15-24$.

Marshall I. T. 1986. Systematics of the genus Mus. Curr. Top. Microbiol. \& Immunol. 127: 12 - 18.

Meshkova N. N., Kotenkova E. V. and Lyalyukhina S. I. 1984. Osobennosti povedenija domovoj i kurgančikovoj myšej v situacjach novizny. [In: Gryzuny. Materialy VI Vsesojuznogo sovescanija, Leningrad]. Nauka: $268-269$.

Meshkova N. N., Kotenkova E. V. and Lyalyukhina S. I. 1986. Behaviour patterns of Mus musculus and M. hortulanus familiarizing themselves with a new area. Zool. Ž. 65: 123 - 133. [In Russian with English summary]

Mezherin S. V. 1987. Sravnitel'nyj analiz elektroforetičeskich spektrov belkov i fermentov trech form domovych myšej. Doklady AN SSSR 297: 503 - 505. 
Mezherin S. V. and Kotenkova E. V. 1989. Geneticeskoje markirovanie podvidov domovych mysej Fauny SSSR. Doklady AN SSSR 304, 5: 1272 - 1275.

Mezherin S. V. and Zagorodnyuk I. V. 1989. Morphological, karyological and genetical divergence of the house mice and mound-building mice. In: House mouse. V. E. Sokolov, E. V. Kotenkova, N. N. Meshkova and B. R. Krasnov, eds]. Moskva: 99 - 114. [In Russian]

Migulin O. O. 1937. Kurgančikova miša jak vid M. sergii Valch. Zb. prac. zool. Muzeju. AN USSR Kiiv: $115-120$.

Naumov N. P. 1940. Ekologija kurganičkovoj myši Mus musculus hiortulanus Nordm. Tr. Inst. evoluc. Morfol. 3: $33-76$.

Ognev S. I. 1916. Mlekopitajuščie Tavričeskoj gubernii, preimuščestvenno Krymskogo poluostrova. Gryzuny. Zap. krym. Obšč. Estestvoispytatelej i Ljubit. Prir. 5: 51 - 111.

Orsini Ph., Bonhomme F., Britton-Davidian J., Croset H., Gerasimov S. and Thaler L. 1983. Le complexe d'especes du genre Mus en Europe Centrale. Z. Säugetierk. 48: 86 - 95.

Pisareva M. E. 1948. K ekologii i sistematike kurgančikovoj myši. Naučnye Zapiski Dnepropetrovskogo Gosuniversiteta, Biol. Fakul'tet 38: $101-110$.

Schwarz E. and Schwarz H. K. 1943. The wild and commensal stocks of the house mouse, Mus musculus Linnaeus. J. Mammal. 24: $59-72$.

Sokolov V. E., Lyalyukhina S.I. and Kotenkova E. V. 1983. A comparative study of responces to olfactory stimuli in the house and mound-building mice (Rodentia, Muridae). Zool. Ž. 62: 1394 - 1398. [In Russian with English summary]

Sokolov V. E., Kotenkova E. V. and Lyalyukhina S. J. 1984. The role of smells in recognition of closely related forms in the house (Mus musculus) and mound-building (M. hortulanus) mice. Zool. Ž. 63: 429 - 439. [In Russian with English summary]

Sokolov V. E., Kotenkova E. V. and Lyalyukhina S. I. 1990. Biology of the house and mound-building mice. Nauka Moskva: 1 - 207. [In Russian]

Sharleman M.B. 1937. Zabytyj vid myši. Priroda 4: 122 - 125.

Thaler L., Bonhomme F., Britton-Davidian J. and Hamar M. 1981a. The house mouse complex of species: sympatric occurrence of biochemical groups Mus 2 and Mus 4 in Rumania. Z. Säugetierk. 46: 169 - 173

Thaler L., Bonhomme F. and Britton-Davidian J. 1981b. Processes of speciation and semi-speciation in the house mouse. [In: Biology of house mouse. R. J. Berry, ed.]. Symp. zool. Soc. Lond. 47: 27 - 41.

Thaler L. 1986. Approche paléontologique et genetique de l'évolution des rongeurs. La Vie des Sciences. Compt. rendus, Sér. generale. 3: 103 - 120 .

Val'ch B. S. 1927. O novom vide myši (Mus sergii sp. n.). Tr. Char'kov. Obšč. Ispytatelej Prir. 50: 49 - 50.

Varshavskij S. N. 1950. Opredelenie vozrosta kurgančikovoj i domovoj myšej. Bjull. mosk. Obšč. Isp. Prir., Ser. biol. $55,6: 21-34$

Received 15 February 1990, accepted 27 February 1991. 